\title{
ESTIMATES OF PRODAN'S SAMPLING METHOD APPLIED TO NELDER'S SYSTEMATIC DESIGN
}

\author{
Franciele Alba da Silva ${ }^{1 *}$, Sylvio Péllico Netto², Alexandre Behling², Ataídes Marinheski Filho ${ }^{4}$, Cláudio \\ Cerqueira Ciqueira ${ }^{5}$ \\ 1* Federal University of Paraná, Department of Forest Science, Curitiba, Paraná, Brasil - francielealba47@ gmail.com \\ ${ }^{2}$ Federal University of Paraná, Department of Forest Science, Curitiba, Paraná, Brasil - sylviopelliconetto@ gmail.com \\ ${ }^{3}$ Federal University of Paraná, Department of Forest Science, Paraná, Brasil - alexandre.behling@yahoo.com.br \\ ${ }^{4}$ Company Brasil Florestal, Canoinhas, Santa Catarina, Paraná, Brasil - amf@brasilflorestal.com \\ ${ }^{5}$ Company Eco Brasil Florestas Brasil Florestal, Tocantins, Brasil - ccc@ecobrasilflorestas.com.br
}

Received for publication: 07/02/2019 - Accepted for publication: 05/07/2019

\begin{abstract}
Resumo
Estimativas dendrométricas de Prodan obtidas em delineamento sistemático de Nelder. A amostragem de Prodan apresenta características relevantes para se obter estimativas das variáveis dendrométricas por hectare em delineamento sistemático de Nelder, pois é um método prático e mantém o número de árvores amostradas em todas as unidades amostrais para os diferentes espaçamentos. Desse modo, o objetivo da pesquisa foi avaliar o comportamento da amostragem de Prodan nas estimativas das variáveis: número de árvores, área basal e volume por hectare, em diferentes espaçamentos, sob a hipótese de que essas estimativas apresentam comportamento decrescente com o aumento do espaçamento. Os dados utilizados no estudo são de um experimento com nove círculos (espaçamentos) de Nelder, implantados com dez clones de Eucalyptus spp., no estado do Tocantins, Brasil. A partir do centro da unidade amostral - UA foi selecionada uma árvore referência, e as oito árvores mais próximas compuseram a UA. A estimativa das variáveis dendrométricas foram calculadas utilizando os estimadores do método de Prodan. Para avaliar as diferenças estatísticas entre as estimativas dos clones e entre seus espaçamentos, foi utilizada a análise multivariada de perfis. As variáveis dendrométricas resultaram em comportamento decrescente em relação ao aumento do espaçamento. O número de árvores é mais influenciada pelo espaçamento. As estimativas de área basal e volume por hectare foram também influenciadas pelo número de árvores, material genético das plantas e mortalidade. A amostragem de Prodan é apropriada e prática para se obter estimativas por hectare em círculos de Nelder, pois não há necessidade de medir todas as árvores do experimento.
\end{abstract}

Palavras-chave: Método amostral. Espaçamento. Estimativas amostrais.

\begin{abstract}
Prodan's sampling method presents relevant characteristics to obtain estimates of the dendrometric variables per hectare in a Nelder systematic design, because it is practical method and maintains the same number of trees sampled in all sample units for the different spacings. The objective of the research was to evaluate the performance of the estimates number of trees, basal area, and volume per hectare in different spacings with the Prodan's sampling method, under the hypothesis that these estimates show decreasing behavior with increasing spacing. The data used in the study are from an experiment with nine Nelder plots, established with ten clones of Eucalyptus spp., in the state of Tocantins, Brazil. From the center of the sample unit $-S U$ a reference tree was selected, and the eight nearest trees composed the $S U$. The estimates of number of trees, basal area and volume per hectare were calculated using the Prodan's method estimators. Statistical differences between the estimates of the clones and between their spacing were evaluated by multivariate profile analysis. The behavior of the dendrometric variables was inversely proportional to spacing, that is, their estimates decreased with the increase of spacing. The number of trees is more influenced by spacing, and additionally with plant genetic material and mortality also influenced estimates of basal area and volume per hectare. Prodan's sampling method is appropriate and practical to obtain the estimates per hectare in Nelder's design because it is not necessary to measure all the trees of the experiment.

Keywords: Sample method. Tree spacing. Sampling estimates.
\end{abstract}

\section{INTRODUCTION}

Brazilian experience with the production of Eucalyptus spp. reveals continuous potential gains in productivity, as the rate of increase has been steady for more than 40 years, indicating that such gains are associated with the improvement of the genotype of these species and the practices of forest management. Thus, the challenge of forestry is about to design and use of management systems that maintain or allow the increase in the rate of growth and the quality of the wood, managing the supply and use of resources. Spacing specification is one of the

FLORESTA, Curitiba, PR, v. 50, n. 3, p. 1585 - 1594, jul/set 2020.

Silva, F. A. et.al.

ISSN eletrônico 1982-4688

DOI: $10.5380 /$ rf.v50 i3. 64837 
most important and influential factors in forest production, as it influences the stand performance with the cutting age, the silvicultural practices employed, and, consequently, with production costs (ELOY et al., 2013).

Nelder (1962) presented an experimental design that makes it possible to test different planting spacing, where the trees are distributed at intersections of radii and concentric arcs, forming different densities. Estimates of number of trees and volume per hectare are usually obtained in Nelder systematic designs, using the ratio between the value of one hectare and the individual area per plant, whereas the volume per hectare is estimated using mathematical models that convert it to an area of one hectare (RIBEIRO et al., 2017; ODA-SOUZA et al., 2008). However, due to the fact that the experiment is not randomized, it causes uncertainty in the statistical analysis interpretation (MORAES et al., 2013), and in the extrapolation of the results per hectare, making it difficult to use classical statistical analyzes. Thus, applying a sampling method to obtain the estimates of the number of trees, basal area, and volume per hectare in Nelder's systematic design becomes interesting from a methodological standpoint.

The characteristics of Prodan's method allow to be used appropriately in the Nelder design, since the selection of trees to be included in the sample units is proportional to their distance to a center point of the each plot. Therefore, the number of trees sampled by the Prodan's method is the same in all sample units for the different spacing, consequently there is a reduction in variability between the sample units, which would not be possible with the fixed area method.

The researches performed using the Prodan's method generally aim to compare it with other sampling methods of variable area, such as the Bitterlich and Strand methods (GOMES et al., 2011; ARAÚJO et al., 2018), or even with the fixed area method (TÉO et al., 2014; MIRANDA et al., 2015). Nevertheless, there are no studies that aim to analyze the behavior of the estimates of number of trees, basal area, and volume per hectare estimated by the Prodan's method in different spacings.

The objective of this research was to evaluate the behavior of the Prodan's method in the estimates of number of trees, basal area, and total volume per hectare, for eucalyptus clones in different spacing, in the adapted Nelder's systematic design. The work was based on the hypothesis that the estimated variables per hectare show a decreasing behavior with the increase of the vital area per tree, since in more densely populated areas there are a greater number of trees.

\section{MATERIAL AND METHODS}

\section{Study area}

The data used in the study came from an experiment with ten Eucalyptus spp. clones, distributed in nine Nelder plots, located in the northern state of Tocantins, Brazil (FIGURE 1). The experiment was established from 2010 to 2014, therefore the Nelder plots have different ages.

The region where the experiment was established is characterized by a semi-humid tropical Aw type of climate in the Köppen's classification, with high temperatures throughout the year, with a minimum of $20^{\circ} \mathrm{C}$ and a maximum of $32^{\circ} \mathrm{C}$, presenting a defined rainy season, between the months of October to May, and a dry season, between the months of June to September, with annual precipitation above 1,800 mm (SILVA JÚNIOR, 2016).

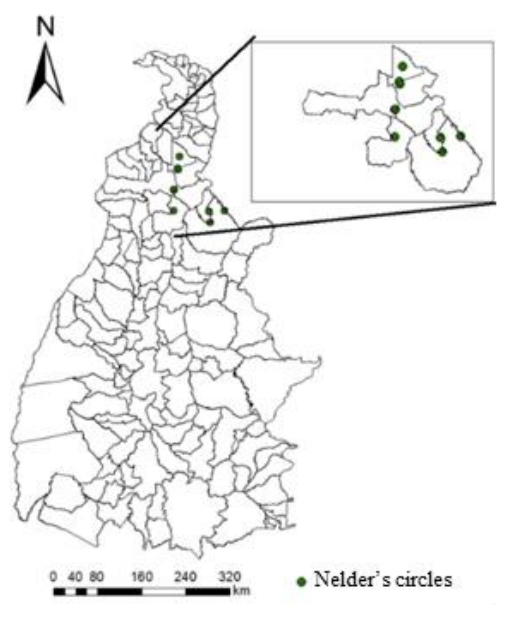

Figura 1. Localização dos círculos de Nelder no estado de Tocantins. Figure 1. Location of Nelder circles in the state of Tocantins. 
The design used in the present study has the same spacing between the plants along the radius, therefore it is not necessary to use the ratio of the geometric progression $(\alpha)$ along the rays. As the value of the initial radius was used with the same spacing between trees (approximately 3 meter), the area occupied per tree was calculated using only the constant distance between trees in the radius and the growing distance between arcs, delimited by the opening angle of two radii $(\theta)$. Due to these characteristics, Nelder plots were considered an adaptation, because in the original systematic design Nelder (1962) proposed that, in the experimental arrangement, values of the initial ray $\mathrm{r}_{0}$ (distance from the center of the circle to the inner border) be defined, as a ratio of the geometric progression of the rays $(\alpha)$, the angle between them $(\theta)$ and the area (Ai) per tree.

The eucalyptus clones have distinct characteristics and are organized by letters. Two to four different eucalyptus' clones were planted in each Nelder's circle, and to identify in which of them the clone is located, an alphanumeric coding was created, with the letter representing the clone and the number of the Nelder's circle in brackets. The characteristics are described below:

A: Urograndis hybrid, high productivity, and medium drought resistance, B: Urograndis hybrid, high yielding clone with low drought resistance and phytosanitary problems in low areas, C: Urograndis hybrid, high yielding and medium drought resistant, D: Urograndis hybrid, high yield and low drought resistance, E: Urograndis hybrid, high yield and medium drought resistance, F: Urocam hybrid, medium yield and high drought resistance, G: Urograndis hybrid, high yield, low drought resistance and phytosanitary problems in low areas, H: Eucalyptus platyphylla, medium yield, high drought resistance and phytosanitary problems in low areas, I: Eucalyptus platyphylla, medium yield, high drought resistance, J: Urograndis hybrid, high yield, medium drought resistance.

\section{Data collection}

The sample units were allocated making an adaptation to the Prodan's method by taking a tree as the central point of the sample units, called the reference tree and the other trees closest to it, called neighboring trees, composed the sample unit (FIGURE 1a). As a result, the sampling units within the adapted Nelder design were composed of eight neighboring trees closest to the reference tree, totaling nine trees in the sample. The reference tree was chosen in a systematic way to better represent the different spacing, and was not accounted for in the calculations of the estimates of the variables under study. We have opted for a systematic choice for better representation of the different spacing, which would not be guaranteed with the random choice of the reference tree.

Péllico Netto and Brena (1997) describe that the distance or radius of the sixth tree is used as reference to the size of the Prodan's sample unit. In this work, the distance from the eighth tree was used, being this selected randomly between the seventh and the eighth tree, since due to its systematic structure, in Nelder's systematic design these two trees have the same distance from the reference tree (FIGURE 2b).

The sample units were systematically arranged along the rays of the adapted Nelder plots in order to represent the different spacings. One sample unit was allocated to each spacing class, totaling four sample units per clone. The spacing classes were characterized as:

- Class I: Very dense, with vital area per tree smaller than $5.9 \mathrm{~m}^{2}$,

- Class II: Dense, with a vital area per tree between $6 \mathrm{~m}^{2}$ and $10.9 \mathrm{~m}^{2}$,

- Class III: Moderate densification, with vital area per tree between $11 \mathrm{~m}^{2}$ to $15.9 \mathrm{~m}^{2}$,

- Class IV: Not dense, with a vital area per tree greater than $16 \mathrm{~m}^{2}$.
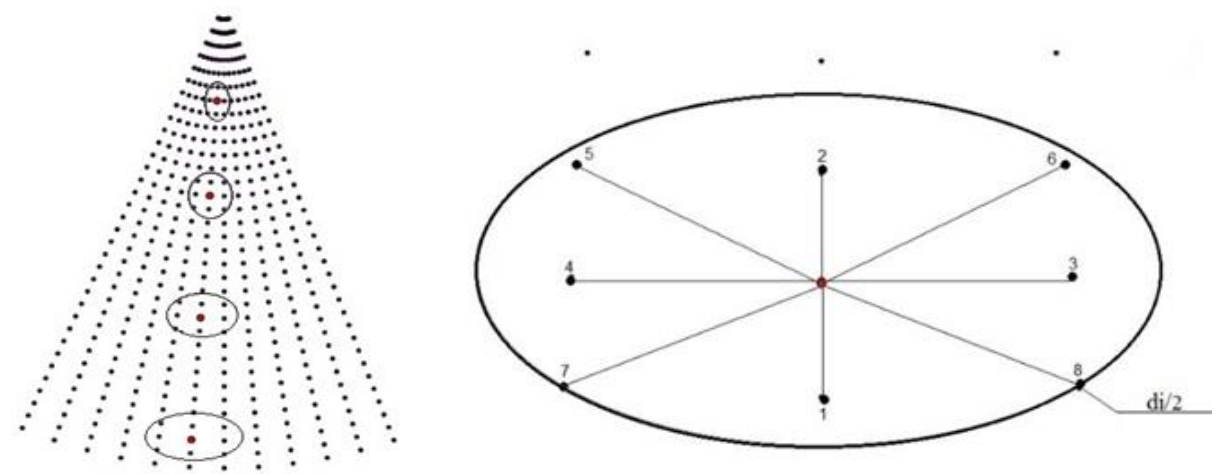

a)

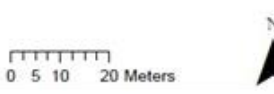

- Reference tree

- Neighboringtree

b)

FLORESTA, Curitiba, PR, v. 50, n. 3, p. 1585 - 1594, jul/set 2020.

Silva, F. A. et.al.

ISSN eletrônico 1982-4688 
Figura 2. a) Croqui representativo da disposição das unidades amostrais ao longo dos raios de um clone no círculo de Nelder adaptado. b) croqui representativo de uma unidade amostral pelo método de Prodan, localizada na classe de espaçamento IV, em que di é diâmetro da oitava árvore.

Figure 2. a) Representative plot of the array of sample units along the radii of a clone in the adapted Nelder circle. b) representative sketch of a sample unit by the Prodan method, located in the class of IV, spacing where di is the diameter of the eighth tree.

The variables measured were diameter at breast height $(D B H)$, with the aid of a tape measure, and total height $(h)$, using the vertex hypsometer. The volume of the trees (v) was obtained using the Schumacher-Hall model (1) fitted and provided by the company holding the data.

$$
v=0.000044487 d^{1.73714816} h^{1.17608127}
$$

where: $v$ is the total volume per tree $\left(\mathrm{m}^{3}\right), d$ is the diameter at breast height $(\mathrm{cm}) ; h$ is the total height $(\mathrm{m})$.

\section{Data processing and analysis}

The number of trees per hectare, basal area $\left(G-m^{2} \cdot a^{-1}\right)$ and volume per hectare $\left(v-m^{3} \cdot a^{-1}\right)$ were calculated using the Prodan's method estimators, presented in Péllico Netto and Brena (1997). Excel 2013 software was used to process the data. The number of trees per hectare (2) and the basal area (3) were calculated using a proportional expansion based on the eight trees in the sample unit. The volume estimates per hectare (4) were obtained using appropriately the volume of each of the 8 trees in the sampling unit.

$$
\begin{gathered}
N=\frac{(7,5)(10.000)}{\pi R_{8}^{2}} \\
\widehat{G}=\frac{d_{1}^{2}+d_{2}^{2}+d_{3}^{2}+d_{4}^{2}+d_{5}^{2}+d_{6}^{2}+d_{7}^{2}+\frac{d_{8}^{2}}{2}}{R_{8}^{2}}(2.500) \\
V=\frac{v_{1}+v_{2}+v_{3}+v_{4}+v_{5}+v_{6}+v_{7}+\frac{V_{8}}{2}}{\pi R_{8}^{2}}(10.000)
\end{gathered}
$$

where: $\mathrm{N}$ is the number of trees per hectare, $\mathrm{G}$ is the basal area $\left(\mathrm{m}^{2} \cdot\right.$ ha- $\left.^{1}\right), V$ is the volume per hectare $\left(\mathrm{m}^{3} \cdot \mathrm{ha}^{1}\right), R_{8}$ is the ray of the eighth tree $(\mathrm{m}), d_{i}$ is the diameter of the $\mathrm{i}^{\text {th }}$ trees in the sample unit $(\mathrm{cm}), v_{i}$ is the estimated volume of the $\mathrm{i}^{\text {th }}$ trees in the sample unit $\left(\mathrm{m}^{3}\right)$.

The behavior of Prodan's method at different spacings were evaluated using dispersion diagrams of the relationship between the estimates of the number of trees, basal area and volume per hectare, and the average area per tree. The Nelder plots have different ages, consequently the eucalyptus clones were separated by age.

\section{Multivariate Profile Analysis}

The difference of clones estimates at different spacings were tested applying multivariate profile analysis, as it bypasses the autocorrelation problem between observations. The analysis was performed comparing the clones in each Nelder plots, seeking to reduce the variability caused by the different locations of the circles.

Three hypotheses were proposed and tested with the profile analysis:

$\mathrm{H}_{0}{ }^{(1)}$ - The average response profiles corresponding to the treatments are parallel. There is no interaction Clones x Spacing, clones,

$\mathrm{H}_{0}{ }^{(2)}$ - The average response profiles of the treatments are coincident. There is no difference among effect.

$\mathrm{H}_{0}{ }^{(3)}$ - The average response profiles of the clones are parallel to the abscissa axis. There is no spacing

The Wilks lambda test $(\lambda)$ was used to evaluate the three hypotheses when three or more clones were analyzed at $95 \%$ probability level. The significance of this test was evaluated by transforming the value of $\lambda$ to a corresponding value of $F$, and its tabulated distribution was used to evaluate the significance. If $F$ calculated $<\mathrm{F}$ the hypotheses $\mathrm{H}_{0}{ }^{(1)}, \mathrm{H}_{0}{ }^{(2)}$ and $\mathrm{H}_{0}{ }^{(3)}$ are accepted, otherwise they are rejected.

Two clones were evaluated by the Hotelling test $\left(\mathrm{T}^{2}\right)$ to verify the significance or not of the hypotheses $\mathrm{H}_{0}{ }^{(1)}$ and $\mathrm{H}_{0}{ }^{(3)}$, by comparing the calculated value with the value of the Hotelling table $\left(\mathrm{T}^{2}\right)$. For hypothesis $\mathrm{H}_{0}{ }^{(2)}$, the $t$-test was used, as described by Rencher (1934).

FLORESTA, Curitiba, PR, v. 50, n. 3, p. 1585 - 1594, jul/set 2020. 
SAS (System Analysis Statistical) was the software used, in the Studio version, with the proc GLM function. This requires the data to be complete in the experimental units, with no plots lost. The Matlab software was used to perform the analysis between two clones.

The homogeneity of the variances was verified by Bartlett's test at $95 \%$ probability level. Logarithmic transformation was used to adjust the data to the model's assumptions.

\section{RESULTS}

The estimates of number of trees, basal area and volume per hectare, showed significant differences in different spacing for the Eucalyptus ssp. clones under study, by checking the rejection of the hypothesis $\mathrm{H}_{0}{ }^{(3)}$ in the multivariate profile analysis for the three variables, in all Nelder plots (TABLE 1), thus indicating the effect of spacing on the estimates of the variables per hectare. In general, the behavior of the three variables estimated with Prodan's method decreased with the increase of the vital area, presenting the highest values in the smallest spacing classes.

Estimates of the number of trees per hectare decreased more expressively with the increase in vital area, showing little variation between clone values (FIGURE 3). The results were coincident and did not differ statistically for the estimates of this variable since hypothesis $\mathrm{H}_{0}{ }^{(2)}$ was accepted for all Nelder plots. Hypothesis $\mathrm{H}_{0}{ }^{(1)}$ was also accepted for this variable, showing that there is no interaction between clones at different spacings, and the response profiles are parallel for the different clones (TABLE 1).

The estimates of the variables basal area and volume per hectare resulted in similar behavior as occurred to the number of trees, showing decreasing values with the increase of spacing, and resulted in higher values in the lower spacing, between classes I and II (FIGURES 4 and 5). Only clone A (N6), at the age of three and a half years (FIGURE 3) showed the highest values in spacing class III.

When analyzing the behavior of the estimates of basal area and volume per clone, at the ages of two, three, three and a half, and five years (FIGURES 4 and 5), they showed a notable difference in the smallest spacing (class I and II). This difference had reduced with the increase in spacing, and at the highest spacing (class IV), the values of the clone estimates came closer to each other. Estimates of basal area and volume per hectare for fouryear-old clones also showed this behavior, but there was little reduction in the difference between the estimated values with increased spacing. A slight decrease in values of these variables can be observed for five-year-old clones.

The behavior of the basal area estimates for the different clones and ages was coincident. However, some clones had higher values (FIGURE 5). Clones I (N5) at two years, E (N9) and C (N9) at three years, E (N6) and G (N6) at three and a half years, B and A (N7) at four years, presented higher values than the others, but did not differ statistically by acceptance of the hypothesis $\mathrm{H}_{0}{ }^{(2)}$, indicating that the clones are coincident. For this variable only at the age of five years (Nelder plot 2) the estimates among the clones presented a difference, with profiles of the clones not coincident, with a better performance of the estimates for clone E, in spacing class II. Hypothesis $\mathrm{H}_{0}{ }^{(1)}$ was rejected for clones in the Nelder plots 3 and 4 , indicating that the clones of those circles present an interaction between the estimates of basal area and the spacing.

The volume estimates per hectare followed the same trend as the basal area, due to the clones in the Nelder plots 2, 3, 4 and 8 were not coincident, i.e., they were statistically different, as the hypothesis $\mathrm{H}_{0}{ }^{(2)}$ was rejected. The clones of these Nelder plots, E(N2), I(N3) and $\mathrm{H}(\mathrm{N} 5)$, were superior in volume estimates per hectare. The clones in the Nelder plots 4 and 8 showed interaction between volume and spacing estimates, as $\mathrm{H}_{0}{ }^{(1)}$ was rejected.

Tabela 1. Análise multivariada para o efeito dos fatores espaçamento, clone e interação (espaçamento x clone), para as variáveis dendrométricas: área basal, volume e número de árvores por hectare, para clones de Eucalyptus spp. em delineamento sistemático de Nelder, no estado do Tocantins, Brasil.

Table 1. Multivariate analysis for the effect of spacing, clone and interaction factors (clone x spacing), for basal area, volume and number of trees per hectare, for clones of Eucalyptus spp. in a systematic design of Nelder, in the state of Tocantins, Brazil.

\begin{tabular}{cccccc}
\hline \multirow{2}{*}{ Nelder plot } & Hypotheses & \multicolumn{3}{c}{ Calculated Statistics } & Tabulated statistics \\
\cline { 3 - 5 } & & $\mathrm{G}\left(\mathrm{m}^{2} \cdot \mathrm{ha}^{-1}\right)$ & $\mathrm{V}\left(\mathrm{m}^{3} \cdot \mathrm{T}^{2}, \mathrm{~h}\right)$ & $\mathrm{N}\left(\mathrm{N}^{-1} \mathrm{ha}^{-1}\right)$ & 22.72 \\
\hline \multirow{2}{*}{1} & $\mathrm{H}_{0}{ }^{(1)}$ & $13.07^{\mathrm{ns}}$ & $6.77^{\mathrm{ns}}$ & $19.51^{\mathrm{ns}}$ & 2.77 \\
& $\mathrm{H}_{0}{ }^{(2)}$ & $-0.4^{\mathrm{ns}}$ & $1.00^{\mathrm{ns}}$ & $0.31^{\mathrm{ns}}$ & 22.72 \\
\hline & $\mathrm{H}_{0}{ }^{(3)}$ & $92.32^{*}$ & $106.93^{*}$ & $22.80^{*}$ & 3.58 \\
\hline & $\mathrm{H}_{0}{ }^{(1)}$ & $1.46^{\mathrm{ns}}$ & $3.62^{\mathrm{ns}}$ & $0.53^{\mathrm{ns}}$ & 5.14 \\
\hline
\end{tabular}

FLORESTA, Curitiba, PR, v. 50, n. 3, p. 1585 - 1594, jul/set 2020.

Silva, F. A. et.al.

ISSN eletrônico 1982-4688 


\begin{tabular}{|c|c|c|c|c|c|}
\hline & $\mathrm{H}_{0}{ }^{(3)}$ & $79.44 *$ & $27.59 *$ & $654.72 *$ & 4.76 \\
\hline & $\mathrm{H}_{0}^{(1)}$ & $2.75 *$ & $2.08^{\mathrm{ns}}$ & $1.50^{\mathrm{ns}}$ & 2.65 \\
\hline \multirow[t]{3}{*}{3} & $\mathrm{H}_{0}^{(2)}$ & $2.51^{\mathrm{ns}}$ & $6.22 *$ & $0.76^{\mathrm{ns}}$ & 4.07 \\
\hline & $\mathrm{H}_{0}^{(3)}$ & $23.06^{*}$ & $15.25^{*}$ & $383.34 *$ & 3.86 \\
\hline & $\mathrm{H}_{0}(1)$ & $25.20 *$ & $25.77 *$ & $2.02^{\mathrm{ns}}$ & 22.72 \\
\hline \multirow[t]{3}{*}{4} & $\mathrm{H}_{0}^{(2)}$ & $1.32^{\mathrm{ns}}$ & $1.40^{\mathrm{ns}}$ & $-0.37^{\mathrm{ns}}$ & 2.77 \\
\hline & $\mathrm{H}_{0}^{(3)}$ & $205.64 *$ & $177.28 *$ & $38.41 *$ & 22.72 \\
\hline & $\mathrm{H}_{0}{ }^{(1)}$ & $1.14^{\mathrm{ns}}$ & $2.83^{\mathrm{ns}}$ & $2.81^{\mathrm{ns}}$ & 22.72 \\
\hline \multirow[t]{3}{*}{5} & $\mathrm{H}_{0}^{(2)}$ & $0.36^{\mathrm{ns}}$ & $1.89^{\mathrm{ns}}$ & $0.07^{\mathrm{ns}}$ & 2.77 \\
\hline & $\mathrm{H}_{0}(3)$ & $608.22 *$ & $233.33^{*}$ & $37.6 *$ & 22.72 \\
\hline & $\mathrm{H}_{0}{ }^{(1)}$ & $2.10^{\mathrm{ns}}$ & $2.10^{\mathrm{ns}}$ & $0.74^{\mathrm{ns}}$ & 3.58 \\
\hline \multirow[t]{3}{*}{6} & $\mathrm{H}_{0}^{(2)}$ & $3.34^{\mathrm{ns}}$ & $3.34^{\mathrm{ns}}$ & $0.34^{\mathrm{ns}}$ & 5.14 \\
\hline & $\mathrm{H}_{0}^{(3)}$ & $44.18 *$ & $44.18 *$ & $6734.27 *$ & 4.76 \\
\hline & $\mathrm{H}_{0}{ }^{(1)}$ & $1.46^{\mathrm{ns}}$ & $1.27^{\mathrm{ns}}$ & $1.20^{\mathrm{ns}}$ & 3.58 \\
\hline \multirow[t]{3}{*}{7} & $\mathrm{H}_{0}^{(2)}$ & $5.00^{\mathrm{ns}}$ & $2.43^{\mathrm{ns}}$ & $2.19^{\mathrm{ns}}$ & 5.14 \\
\hline & $\mathrm{H}_{0}^{(3)}$ & $50.22 *$ & $48.82 *$ & $5920.67 *$ & 4.76 \\
\hline & $\mathrm{H}_{0}{ }^{(1)}$ & $2.59^{\mathrm{ns}}$ & $3.64 *$ & $1.30^{\mathrm{ns}}$ & 2.65 \\
\hline \multirow[t]{3}{*}{8} & $\mathrm{H}_{0}^{(2)}$ & $3.63^{\mathrm{ns}}$ & $4.66^{*}$ & $0.76^{\mathrm{ns}}$ & 4.07 \\
\hline & $\mathrm{H}_{0}(3)$ & $33.54 *$ & $17.29 *$ & $369.921 *$ & 3.86 \\
\hline & $\mathrm{H}_{0}{ }^{(1)}$ & $1.14^{\mathrm{ns}}$ & $0.91^{\mathrm{ns}}$ & $2.52^{\mathrm{ns}}$ & 3.58 \\
\hline \multirow[t]{2}{*}{9} & $\mathrm{H}_{0}(2)$ & $2.80^{\mathrm{ns}}$ & $2.02^{\mathrm{ns}}$ & $4.77^{\mathrm{ns}}$ & 5.14 \\
\hline & $\mathrm{H}_{0}^{(3)}$ & $46.59 *$ & $29.23^{*}$ & $250.25^{*}$ & 4.76 \\
\hline
\end{tabular}

Where: * is significant at $95 \%$ probability level; ns is not significant at $95 \%$ probability level.
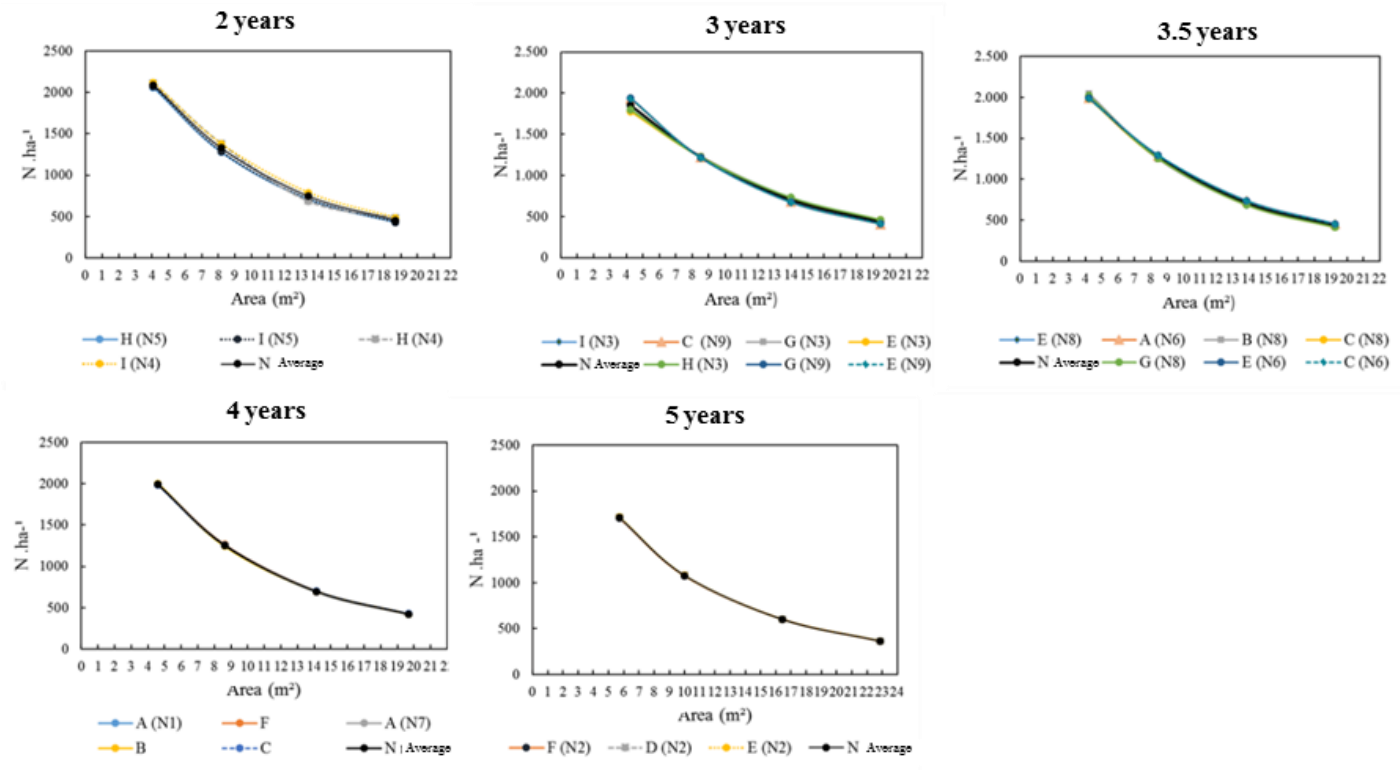

Figura 3. Estimativas da variável número de árvores (n.ha-1) por clone e média por hectare para os clones de Eucalyptus spp nos círculos de Nelder, localizados no estado do Tocantins.

Figure 3. Estimates of the variable number of trees (n.ha-1) per clone and average per hectare for the Eucalyptus spp clones in the Nelder plots, located in the state of Tocantins. 

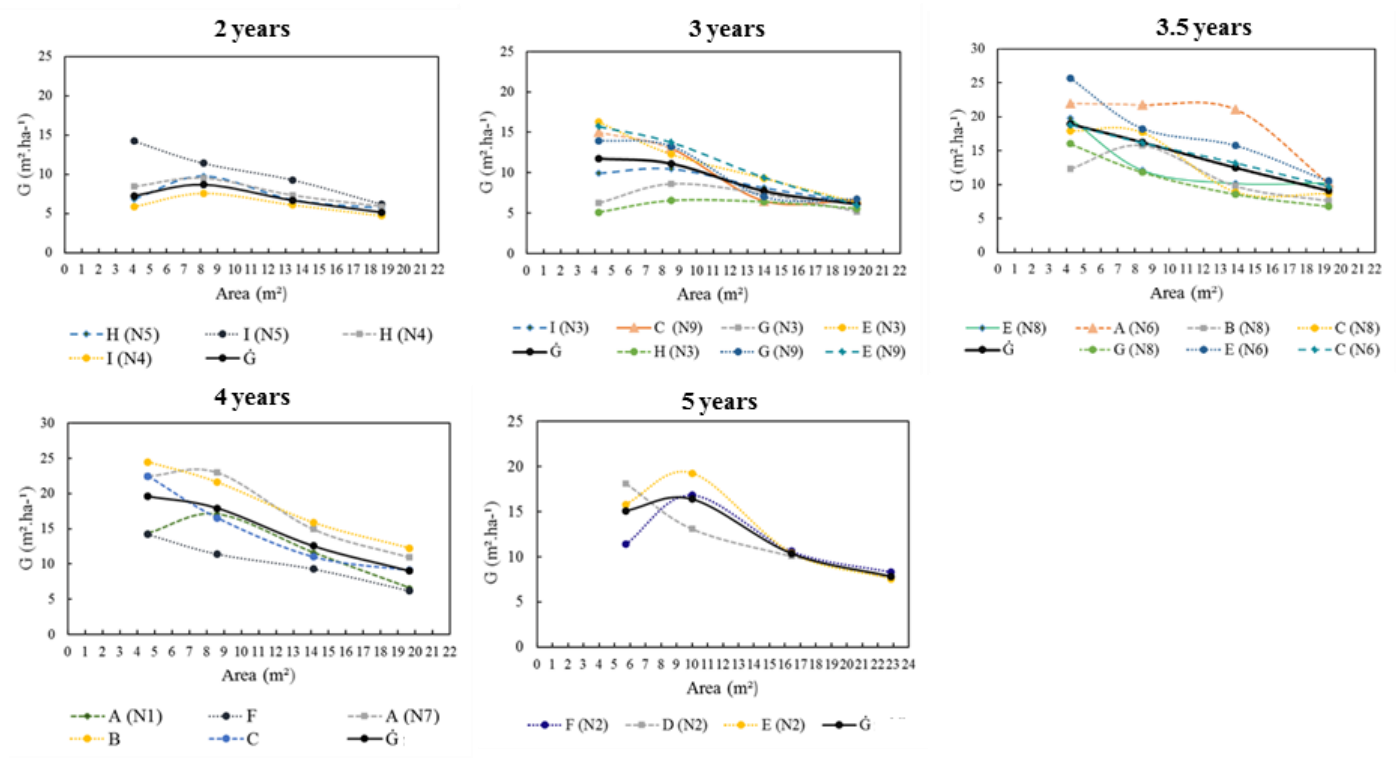

Figura 4. Estimativas da variável área basal $\left(\mathrm{m}^{2} \cdot \mathrm{ha}^{-1}\right)$ por clone e média por hectare para os clones de Eucalyptus spp nos círculos de Nelder, localizados no estado do Tocantins.

Figure 4. Estimates of the variable basal area $\left(\mathrm{m}^{2} \cdot \mathrm{ha}^{-1}\right)$ per clone and average per hectare for Eucalyptus spp clones in Nelder plots, located in the state of Tocantins.
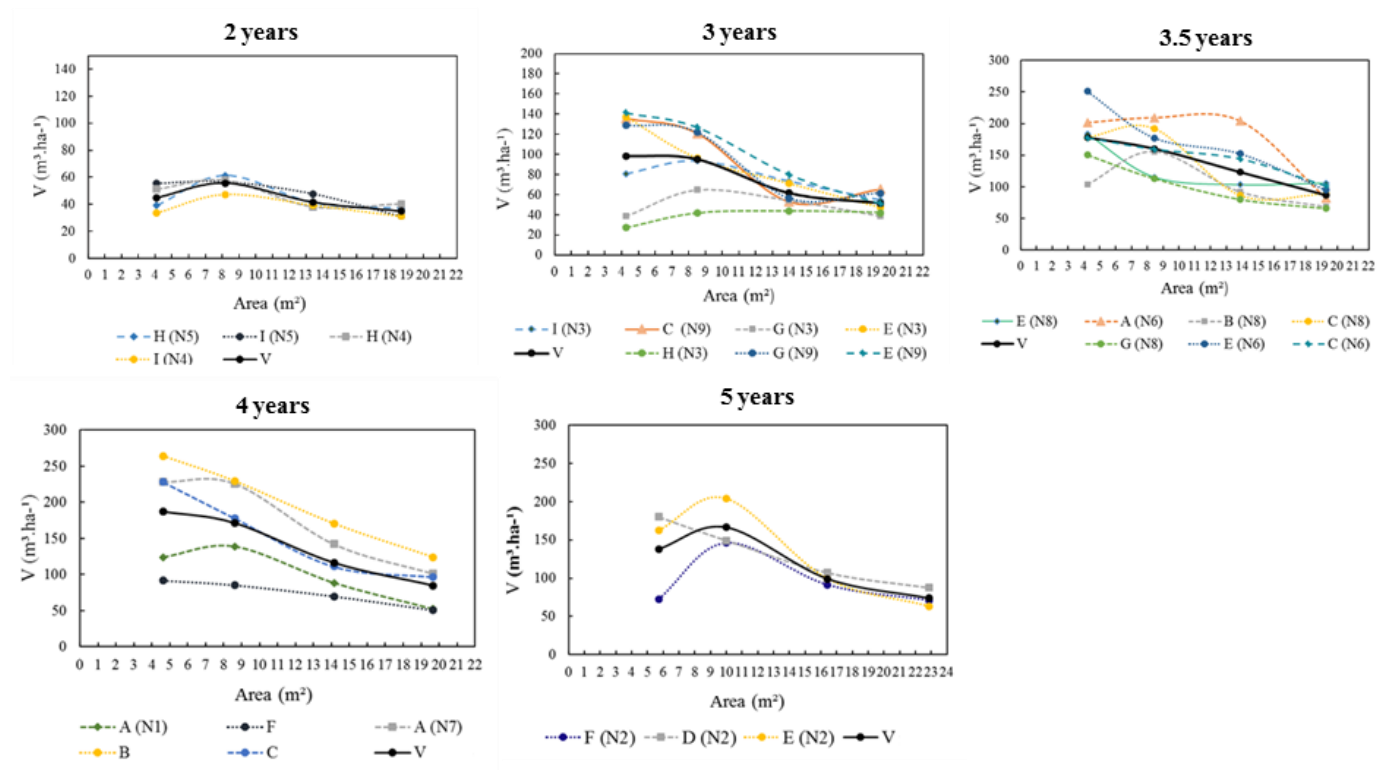

Figura 5. Estimativas do volume $\left(\mathrm{m}^{3} \cdot \mathrm{ha}^{-1}\right)$ por clone e média por hectare para os clones de Eucalyptus spp nos círculos de Nelder, localizados no estado do Tocantins.

Figure 5. Estimates of the volume $\left(\mathrm{m}^{3} \cdot \mathrm{ha}^{-1}\right)$ per clone and average per hectare for the Eucalyptus spp clones in the Nelder plots, located in the state of Tocantins.

The highest mortality rates were observed in spacing class I (FIGURE 6), with the highest spacing increasing from $50 \%$ mortality at the ages of three years for clone E (N3) to four years for clones A (N7), A (N1) and C (N7). In the less densely spaced classes, mortality was low (less than 10\%), with the exception of clones E (N6), E (N8) at three and half years of age, and B (N7) at four years of age, who had higher percentage of mortality in spacing class IV than in spacing classes II and III. 


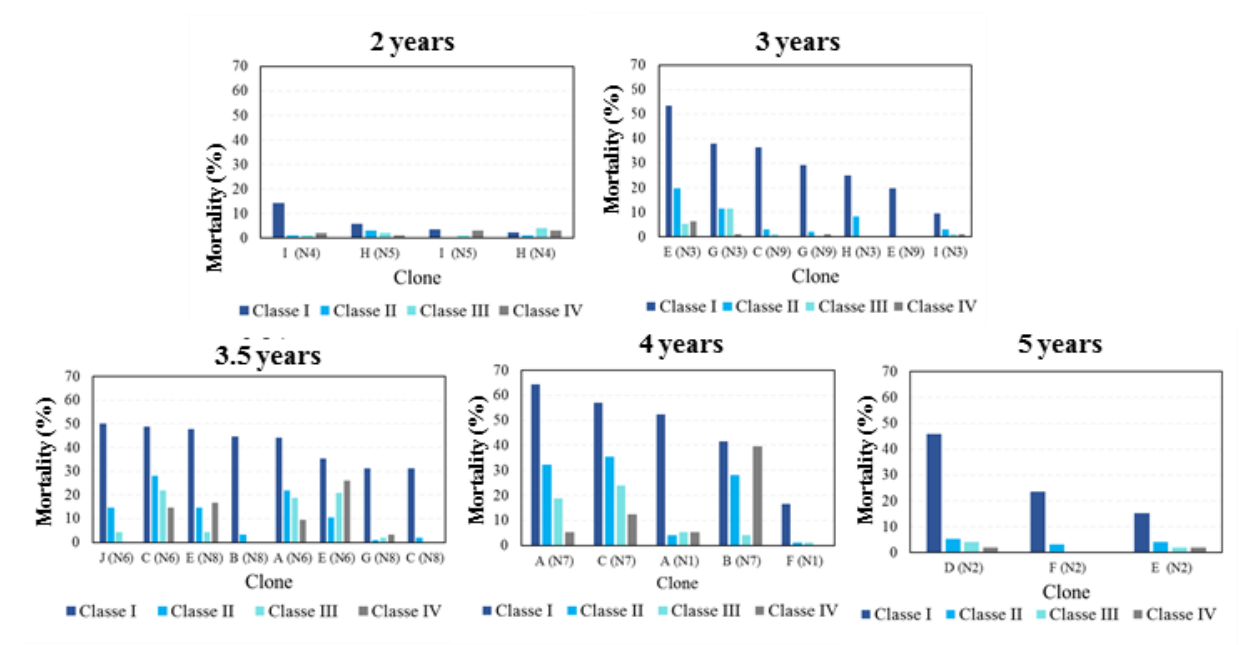

Figura 6. Porcentagem de mortalidade nas diferentes classes de espaçamento para os clones de Eucalyptus spp., em delineamento sistemático de Nelder, estado do Tocantins.

Figure 6. Percentage of mortality in different spacing classes for Eucalyptus spp clones, in systematic design of Nelder, state of Tocantins.

\section{DISCUSSIONS}

The number of trees per hectare is more sensitive and influenced by spacing and less by the genetic material of the clones and mortality than the basal area and volume per hectare, due to the decreasing behavior observed with the increase in vital area, very similar for all clones and age, without statistical difference between clones. According to Kleinn and Vilcko (2006), for smaller distance values $(\mathrm{k})$ to the $\mathrm{n}^{\text {th }}$ tree, when the spatial pattern of the species is aggregated, they generate high values of N.ha-1. Araújo et al. (2018) stated that plants further away from the sampling point cause an increase in the estimator's denominator and, consequently, a reduction in the estimated number of plants. Loetsch et al. (1973) mention the importance of considering that smaller distances are more sensitive to the type of spatial distribution of the population.

The results of basal area and volume estimates for clones with higher values in spacing classes II and III are associated with the percentage of mortality, which was higher in the more densely spaced (class I). Results with higher values of estimates for these variables in class I are expected, since at lower spacings higher production per unit area occurs due to the higher number of individuals at these spacings (OLIVEIRA NETO et al., 2010).

The fact that the basal area and volume per hectare estimates at the age five years in Nelder plots show a decrease compared to the estimates between three and four years old plots is due to the diversity of genetic material and the different local growing conditions, since the Nelder plots are integrated by different clones and are distributed in different locations.

Most of the works that used the Prodan's method were applied in native forests (PÉLICO NETTO et al., 2012; TÉO et al., 2014; NASCIMENTO et al., 2015; ARAÚJO et al., 2018), comparing it with other sampling methods, and although some authors found bias in their estimates, they affirmed that the Prodan's method is efficient in obtaining the estimates per hectare. Péllico Netto et al. (2012), when quantifying dendrometric parameters in native araucaria forest using the Prodan's method, found underestimates for the total volume, but the results found were quite close to those obtained in other locations with similar forest conditions in the state of Parana. Araújo et al. (2018) concluded that the Prodan's method generated overestimation of the number of trees per hectare in cases when Eremanthus erythropappus natural regeneration plants showed an aggregate distribution pattern, however, the authors indicate that when the objective of the sampling is to evaluate the height variable of regenerations, the Prodan's method can be applied normally and with low sample intensity, providing reliable estimates.

According to Loetsch et al. (1973), bias in variable estimates can be explained, in part, due to the heterogeneity of distances between plants in native forests and the distribution pattern of species. Sampling methods based on tree distances provide good results only when the population is homogeneous (LOETSCH et al., 1973). The Nelder's systematic design, despite having different spacing, the distance between trees in the sample units shows little variation, allowing the size of the sample unit, defined by the distance from the central point to the $\mathrm{n}^{\text {th }}$ tree, to be consistent with the spacing of the site. Thus, Prodan's method generated good estimates for this design.

FLORESTA, Curitiba, PR, v. 50, n. 3, p. 1585 - 1594, jul/set 2020.

Silva, F. A. et.al

ISSN eletrônico 1982-4688

DOI: $10.5380 /$ rf.v50 i3. 64837 
Miranda et al. (2015) analyzed different sampling methods in teak stands 12 years old and a vital area of $6 \mathrm{~m}^{2}$, and found that the N.ha- ${ }^{1}$ estimated by Prodan's method was 1,125 trees. This value is close and consistent with the values found in class II, which presents this spacing as the lower-class limit. The authors also reported that the Prodan's method resulted in the smallest measurement time per plot when compared to the fixed area and Bitterlich methods. Gomes et al. (2011) compared the variable area sampling methods of Bitterlich and Prodan in 8 year-old eucalyptus stand, and recommended the Prodan's method, as it was the most accurate and the one that best covered the area, even though the evaluated methods showed the same efficiency for volume estimates. Therefore, the practicality and ease of implementation and use of sampling with probability proportional to a distance in different field conditions makes it a good sampling option (KLEINN; VILCKO, 2006).

In addition, the results obtained by applying the Prodan's method in the Nelder's systematic design allowed to visualize the behavior of the estimators of this method at different spacings, resulting in values of decreasing estimates with increased spacings for number of trees, basal area and volume per hectare. The decreasing behavior in the estimates of number of trees and volume per hectare were also observed in the works of Ribeiro et al. (2017) and Oda-Souza et al. (2008), who used the traditional method of the ratio between the value of one hectare and the individual area per tree to estimate the number of trees per hectare, and mathematical models to estimate the volume per hectare in Nelder's systematic design. Therefore, Prodan's method shows adequate behavior to estimate these variables per hectare, in places with different spacing, such in Nelder's plots.

Due to the systematic structure of Nelder plots, analyses should be performed using statistical methods that consider the spatial autocorrelation between observations. Therefore, the Prodan's method can be used to obtain the estimates of number of trees, basal area and volume per hectare, when the observations collected in Nelder plots present dependence between points, as this method is independent of this assumption, since the application of conventional statistics, such as regression models, assumes that the data are independent. Together, multivariate profile analysis makes it possible to solve the dependency problem. Although it is a little applied analysis to forest data, it is efficient for testing the existence of differences between the described profiles of the clones, besides evaluating existing differences between the clones at different spacing.

According to Parrott et al. (2012), when considering the autocorrelation in parameter estimation, statistical analysis produces a better understanding of the relationship between tree density and the growth variables. Therefore, Prodan's method is efficient and practical to obtain the estimates of the number of trees, basal area, and volume in Nelder's systematic design.

\section{CONCLUSIONS}

- The behavior of the number of trees, basal area and volume per hectare decreases as the vital area per tree increases, presenting the highest values for these variables in the lowest density classes, proving the formulated hypothesis for this work.

- The number of trees is the variable most influenced by the spacing and rays of the $\mathrm{n}^{\text {th }}$ tree, and did not vary for the different clones.

- The estimates of basal area and volume per hectare, besides being affected by the number of trees, are also influenced by the characteristics of the genetic material of the planted clones and mortality or failures in thickened spacing.

- Prodan's method is a good alternative for obtaining the parameters per hectare when the data is autocorrelated.

- The Prodan method is appropriate and practical to obtain estimates per hectare of the number of trees, basal area, and volume, in experiments with Nelder plots, because there is no need to measure all the trees of the experiment.

\section{ACKNOWLEDGEMENTS}

Acknowledgement are presented to the Coordenação de Aperfeiçoamento de Pessoal de Nível Superior (CAPES) for granting a master's scholarship to the first author.

\section{REFERENCES}

ARAÚJO, E. J. G; PÉlliCO NETTO, S; MORAES, V. A; DAVID, H. C; CURTO, R. de A; SCOLFORO, J. R. S. Métodos de amostragem de área variável para a regeneração natural de Eremanthus erythropappus (DC.) MacLeish. Floresta, Curitiba, v. 48, n. 2, p. 265-276, Abr./Jun. 2018.

GOMES, K. B; MACHADO FILHO, A; SILVA, V. P; SILVA, A. G. da. Comparação dos Métodos de Amostragem Casual Simples: Bitterlich e Prodan. Revista Agrogeoambiental, Pouso Alegre, v.3, p. 101-104, Abr. 2011.

FLORESTA, Curitiba, PR, v. 50, n. 3, p. 1585 - 1594, jul/set 2020.

Silva, F. A. et.al.

ISSN eletrônico 1982-4688

DOI: $10.5380 /$ rf.v50 i3. 64837 
HAXTEMA, Z; TEMESGEN, H; MARQUARDT, T. Evaluation of n-tree distance sampling for inventory of headwater riparian forests of western Oregon. Western Journal of Applied Forestry, v. 27, p. 109-117, Jul 2012.

KLEINN, C; VILČKO, F. A new empirical approach for estimation in k-tree sampling. Forest Ecology and Management, Amsterdam, v. 237, p. 522-533, Dec. 2006.

LOETSCH, F.; ZOHRER, F.; HALLER, K. E. Forest Inventory. Wien: BLV Verlagsgesellschaft München. 1973. $469 \mathrm{p}$

MIRANDA, D. L. C.; FRANCIO, J.; SANTOS, SANQUETTA, C. R.; DALLA CORTE, A. P. Precisão e eficiência relativa de métodos de amostragem em teca. Pesquisa florestal brasileira, Colombo, v. 35, n. 83, p. 247-254, jul./set. 2015

MORAES, M. A; MORAES, S. M. B.; SILVA, E. C. B.; KUBOTA, T. Y. K.; SILVA, A. M.; RESENDE, M. D. V.; MORAES, M. L. T. Variação genética em progênies de Jacaranda cuspidifolia Mart. utilizando o delineamento sistemático tipo "leque". Scientia Forestalis, Piracicaba, v. 41, n. 98. p.175-183, jun. 2013.

NASCIMENTO, R. G. M.; SILVA, L. C. R. da; BARBEIRO, L. da S. S.; WOJCIECHOWSKI, J. C.; PÉLLICO NETTO, S.; MACHADO, S. do A. Efeito da árvore marginal nos estimadores populacionais obtidos por métodos de amostragem de área variável. Cerne, Lavras, v. 21, n. 1, p. 125-131, 2015.

NELDER, J.A. New kinds of systematic designs for spacing experiments. Biometrics, Washington, v.18, n.3, p. 283-307, set. 1962.

ODA-SOUZA, M.; BARBIN, D.; RIBEIRO JR, P. J.; STAPE, J. L. Aplicação de métodos geoestatísticos para identificação de dependência espacial na análise de dados de um ensaio de espaçamento florestal em delineamento sistemático tipo leque. Revista Árvore, Viçosa, v. 32, n. 3, p. 499-509, Mai/Jun. 2008.

OLIVEIRA NETO, S. N. DE; REIS, G. G. DOS; REIS, M. DAS G. F.; LEITE, H. G.; NEVES, J. C. L. Crescimento e distribuição diamétrica de Eucalyptus camaldulensis em diferentes espaçamentos e níveis de adubação na região do cerrado de Minas Gerais. Floresta, Curitiba, v. 40, n. 4, p. 755-762, out/dez. 2010.

PARROTT, D. L.; BRINKS, J. S.; LHOTKA, J. M. Designing Nelder wheel plots for tree density experiments. New Forest, v. 43, n. 2, p. 245-254, Mar. 2012.

PÉLLICO NETTO, S.; BRENA, D. A. Inventário Florestal. Curitiba, 1997. 316 p.

PÉlliCO NETTO, S; ORELlANA, E; STEPKA, T. F; LIMA, R; FIGUEIREDO FILHO, A. Comportamento probabilístico dos raios das sextas árvores no método de Prodan e estimativas dos parâmetros dendrométricos para Araucaria angustifolia (Bertol.) Kuntze nativa. Scientia Forestalis, Piracicaba, v. 40, n. 96, p. 517-524, dez. 2012.

PRODAN, M. Forest biometrics. Oxford, Pergamon Press, 1968. 447 p.

RIBEIRO, M. D. dos S. B.; JORGE, L. A. B.; MISCHAN, M. M.; SANTOS, A. L. dos; BALLARIN, A. W. Avaliação da produção de biomassa do fuste de um clone híbrido de Eucalipto sob diferentes espaçamentos. Ciência Florestal, Santa Maria, v. 27, n.1, p. 31-45, jan./mar. 2017.

TÉO, S. J; SCHNEIDER, C. R; FIORENTIN, L. D; COSTA, R. H. da. Comparação de métodos de amostragem em fragmentos de Floresta Ombrófila Mista, em Leblon Régis, SC. Floresta, Curitiba, PR, v. 44, n. 3, p. 3.93 402, jul. / set. 2014.

FLORESTA, Curitiba, PR, v. 50, n. 3, p. 1585 - 1594, jul/set 2020. 